http://dx.doi.org/10.11646/zootaxa.3755.3.2

http://zoobank.org/urn:lsid:zoobank.org:pub:BD7BCD17-73C3-4791-AD4B-95C95B6A711B

\title{
Spazigasteroides a new genus from China with a black face and scutellum in the Syrphini (Diptera: Syrphidae)
}

\author{
KE-KE HUO ${ }^{1,2}$ \\ ${ }^{1}$ School of Biological Sciences \& Engineering, Shaanxi University of Technology, Hanzhong 723001, China. \\ ${ }^{2}$ Bio-resources Key Laboratory of Shaanxi Province, Shaanxi University of Technology, Hanzhong 723000, China. \\ E-mail:huokk@163.com
}

\begin{abstract}
In the present paper, the genus Spazigasteroides gen. nov. (Diptera, Syrphidae), with Spazigasteroides caeruleus sp. nov. as type species, is described from China. The new genus bears the following characters: Head strongly concave posteriorly and closely appressed to thorax so that the bare postpronota are entirely hidden. Face black in ground colour. Antennae short, with basoflagellomeres slightly longer than wide. Scutellum black. Postmetacoxal bridge incomplete. Legs simple, slender. Wing vein $\mathrm{R}_{4+5}$ straight, vein $\mathrm{r}-\mathrm{m}$ at basal third of cell $\mathrm{dm}$. Abdomen petiolate, longer than head and thorax together. Male aedeagus two segmented. Based on the subdivision of Syrphinae by Vockeroth (1992), the new genus belongs to the tribe Syrphini, it is separated from the genera of the tribe Syrphini by both the face and scutellum black. In appearance the new genus is also similar to the genus Spazigaster Rondani, the tribe Bacchini, but it is differentiated from the genera of the tribe Bacchini by the two segmented aedeagus.
\end{abstract}

Key words: Syrphinae, new species, taxonomy, Shaanxi Province, Ningxia Hui Autonomous Region

\section{Introduction}

While conducting a survey for Syrphidae in Shaanxi Province and Ningxia Hui Autonomous Region, an unusual syrphine was encountered that did not belong to any known genus or species. The present paper provides descriptions and figures of the new taxa, together with revisionary notes on the genera of Syrphinae with a black face and scutellum.

Based on adult and larval characters, Thompson (1969) divides the family Syrphidae into three subfamilies: Syrphinae, Eristalinae and Microdontinae. This division has been accepted by most workers. Syrphinae are distinctly differentiated from the other two subfamilies by following main combined characters: head posteriorly strongly concave and closely appressed to the thorax so that postpronota are partly or entirely hidden, postpronotum usually bare, larvae of Syrphinae are usually predaceous.

The subfamily Syrphinae has been grouped into many different tribes or subfamilies (Williston 1886; Shannon 1921, 1922, 1923; Hull 1949; Shiraki, 1949; Goffe 1952; Hartley 1960; Wirth et al. 1965; Dusek \& Laska 1967; Knutson et al. 1975; Smith et al. 1980; Stubbs et al. 1983; Peck 1988; Vockeroth 1969, 1992; Thompson \& Rotheray 1998). Wirth et al. (1965) transfer Pipizini from Eristalinae to Syrphinae based on the larval feeding habits, which division is accepted by some workers and not by others. Williston (1886) erects the tribe Bacchini and the tribe Melanostomini, the former consists of the genera with face considerably narrowed below, and abdomen frequently contracted beyond the base, more or less slender; the latter the genera with black face and scutellum. This division was followed subsequently by most workers, although the two tribes respectively comprised of different genera in the classifications of different authors (Brunetti 1923; Shannon 1921, 1922, 1923; Hull 1949; Goffe 1952; Vockeroth 1969; Knutson et al. 1975; Thompson et al. 1976; Peck 1988; Cheng et al. 1998; Huo et al. 2007). Stubbs et al (1983) divide Syrphinae into three tribes: Syrphini (included Chrysotoxini), Bacchini (included Melanostomatini) and Paragini. The differentiation of the tribe Bacchini from the tribe Syrphini is that 


\section{Acknowledgements}

I am particularly indebted to Ximo Mengual (Zoological Research Museum Alexander Koenig Bonn, Germany), who improved the manuscript and provided valuable advice. I am much obliged to F. Christian Thompson (Department of Entomology, National Museum of Natural History, Smithsonian Institution, Washington, USA) for his important guidance and critical comments on the new taxa. I also thank two anonymous reviewers for their critical review of the manuscript. The research was funded by the National Natural Science Foundation of China (31071966).

\section{References}

Brunetti, E. (1923) Pipunculidae, Syrphidae, Conopidae, Oestridae. Diptera. In: Shipley, A.E. (Ed.), The Fauna of British India, including Ceylon and Burma. Vol. 3. Taylor \& Francis, London, i-xi $+1-424 \mathrm{pp}$.

Cheng, X.-Y., Huang, C.-M.,Yang, J.-K. (1998) Syrphidae. In: Xue, W.-Q. \& Zhao J.-M. (Eds.), Flies of China. Volume 1. Liaoning Science and Technology Press, Shengyang, China, pp. 118-223.

Doesburg, P.H. van. (1955) Report on the syrphid flies, collected by the Fourth Dutch Karakorum Expedition, 1935 (Mededelingen over Syrphidae XIII). Beaufortia, 5, 47-51.

Dusek, J. \& Laska, P. (1967) Versuch zum Aufbau eines natürlichen Systems mitteleuropäischer Arten der Unterfamilie Syrphinae (Diptera). Acta scientiarum naturalium Academiae scientiarum bohemoslovacae, Brno, 1, 349-390.

Fluke, C.L. (1943) A new genus and new species of Syrphidae (Diptera) from Ecuador. Annals Entomological Society of America, 36, 425-431.

Fluke, C.L. (1945) The Melanostomini of the Neotropical region (Diptera, Syrphidae). American Museum Novitates, 1272, 129.

Goffe, E.R. (1952) An outline of a revised classificaton of the Syrphidae (Diptera) on phylogenetic lines. Transactions of the Society for British Entomology, 11, 97-124.

Hartley, J.C. (1960) A taxonomic account of the larvae of some British Syrphidae. Proceedings of the Zoological Society of London, 136, 505-573. http://dx.doi.org/10.1111/j.1469-7998.1961.tb05891.x

Huang, C.-M. \& Cheng, X.-Y. (2012) Fauna Sinica, Insecta. Volume 50, Diptera: Syrphidae, Science Press, Beijing, xxiv + 852 pp.

Hull, F.M. (1949) The morphology and inter-relationship of the genera of syrphid flies, recent and fossil, Transaction of the Zoological Society, London, 26, 257-408.

Huo, K.-K., Ren, G.-D. \& Zheng, Z.-M. (2007) Fauna of Syrphidae from Mt. Qinling-Bashan in China (Insecta: Diptera). Chinese Agricultural Science and Technology Press, Beijing, $512 \mathrm{pp}$.

Huo, K.-K., \& Zheng, Z.-M. (2003) Primary Investigation on Syrphinae (Diptera: Syrphidae) from Qinling-Bashan Mountains (I). Entomotaxonomia, 25, 281-291.

Knutson, L.V., Thompson, F.C. \& Vockeroth, J.R. (1975) Family Syrphidae. In: Delfinodo, M.D. \& Hardy, D.E. (Eds.), A Catalog of the Diptera of the Oriental Region. Vol. 2. The University Press of Hawaii, Honolulu, pp. 324-328.

Li, Z.-H. \& Li, Y.-Z. (1990) The Syrphidae of Gansu Province. China Perspective Press, Beijing, pp. 127.

Lundbeck, W. (1916) Diptera Danica. Genera and species of flies hitherto found in Denmark, Volume 5 (Lonchopteridae, Syrphidae). G. E. C. Gad, Kopenhagen, pp. 603 pp.

McAlpine, J.F. (1981) Morphology and terminology_Adults. In: McAlpine, J.F., Peterson, B.V., Shewell, G.E, Teskey, H.J., Vockeroth, J.R. \& Wood, D.M. (Eds.), Manual of Nearctic Diptera. Vol. 1. Research Branch, Agriculture Canada, Monograph N. 27, Ottawa, Canada, pp. 9-63.

Mengual, X., Stahls, G. \& Rojo, S. (2008) First phylogeny of predatory flower flies (Diptera, Syrphidae, Syrphinae) using mitochondrial COI and nuclear 28S rRNA genes: Conflict and congruence with the current tribal classification. Cladistics, 24, 543-562. http://dx.doi.org/10.1111/j.1096-0031.2008.00200.x

Peck, L.V. (1988) Syrphidae. In: Soos, A. \& Papp, L. (Eds.), Catalogue of Palaearctic Diptera 8 (Syrphidae-Conopidae). Elsevier Science Publishing, Amsterdam \& Akadémiai Kiadó, Budapest, pp. 11-230.

Sack, P. (1932) Syrphidae. In: Lindner, E. (Ed.), Die Fliegen der Palaearktischen Region. E. Schweizerbart'sche Verlagsbuchhandlung, Stuttgart, pp. 427-432.

Smirnov, E.S. (1924) Eine neue Syrphiden-Gattung aus Turkestan. Entomologische Mitteilungen, 13, 94-95.

Shannon, R.C. (1921) A reclassification of the subfamilies and genera of North American Syrphidae (Diptera). Bulletin of the Brooklyn Entomological Society, 16, 65-72 \& 120-128.

Shannon, R.C. (1922) A reclassification of the subfamilies and genera of North American Syrphidae (Diptera). Conclusions. Bulletin of the Brooklyn Entomological Society, 17, 30-42.

Shannon, R.C. (1923) A reclassification of the subfamilies and genera of North American Syrphidae (Diptera). Appendix. Bulletin of the Brooklyn Entomological Society, 18, 17-21. 
Shiraki, T. (1930) Die Syrphidae des Japanischen Kaiserreichs, mit Berücksichtigung benachbarter Gebiete. Memoirs of the Faculty of Science and Agriculture Taihoku imperial University, 1, 1-446.

Shiraki, T. (1949) Studies on the Syrphidae. 1. The classification of the Subfamilies. Mushi, 20, 59-71.

Smith, K.G.V. \& Vockeroth, J.R. (1980) 38. Family Syrphidae In: Crosskey R.W. (Ed.), Catalogue of the Diptera of the Afrotropical Region. British Museum (Natural History), London, pp. 488-510.

Stubbs, A.E. \& Steven, J.F. (1983) British hoverflies: an illustrated identification guide. British Entomological \& Natural History Society, London, $253 \mathrm{pp}$.

Thompson, F.C. (1969) A new genus of Microdontine flies (Diptera: Syrphidae) with notes on the placement of the subfamily. Psyche, 76, 74-85. http://dx.doi.org/10.1155/1969/62102

Thompson, F.C. (1999) A key to the genera of the flower flies (Diptera: Syrphidae) of the Neotropical region including descriptions of new genera and species and a glossary of taxonomic terms. Contributions on Entomology, International, 3 , 322-378.

Thompson, F.C. \& Vockeroth, J.R. (1989) 51. Family Syrphidae. In: Evenhuis, N.L. (Ed.), Catalog of the Diptera of the Australasian and Oceanian Regions. Bishop Museum Press \& E. J. Brill, Honolulu, pp. 437-457.

Thompson, F.C. \& Rotheray, G.E. (1998) Family Syrphidae. In: Papp, L. \& Darvas, B. (Eds.), Manual of Palaearctic Diptera, Vol. 3. Science Herald, Budapest, pp. 81-139.

Thompson, F.C., Vockeroth, J.R. \& Sedman, Y.S. (1976) Chapter 46: Family Syrphidae. In: Papavero, N. (Ed.), A catalogue of the Diptera of the Americas south of the United States. Museum of Zoology of the University of Sao Paulo, Sao Paulo, Brazil, pp.1-195.

Verrall, G.H. (1901) Platypezidae, Pipunculidae and Syrphidae of Great Britain. In: Verrall, G.H. (Ed.), British Flies. Vol. VIII. Gurney \& Jackson, London, pp. 19-683.

Vockeroth, J.R. (1969) A revision of the Genera of the Syrphini (Diptera Syrphidae). Memoirs of the Entomological Society of Canada, 62, 1-176. http://dx.doi.org/10.4039/entm10162fv

Vockeroth, J.R. (1973) Some new or uncommon Syrphini (Diptera: Syrphidae) from southern Africa. Annals of the Natal Museum, 21, 595-607.

Vockeroth, J.R. (1992) The flower flies of the subfamily Syrphinae of Canada, Alaska, and Greenland (Diptera: Syrphidae). Insects and Arachnids of Canada, 18. Research Branch, Agriculture Canada, Ottawa, Publication 1867, 456 pp.

Williston, S.W. (1886) Synopsis of the North American Syrphidae. Bulletin of the United States National Museum, 31, xxx + $335 \mathrm{pp}$.

Wirth, W.W., Sedman, Y.S. \& Weems, H.V. (1965) Family Syrphidae. In: Stone, A., Sabrosky, C.W., Wirth, W.W., Foote, R.H. \& Coulson, J.R. (Eds.), A Catalog of the Diptera of America North of Mexico. Agricultural Research Service, United States Department of Agriculture, Washington, DC, pp. 557-625. 